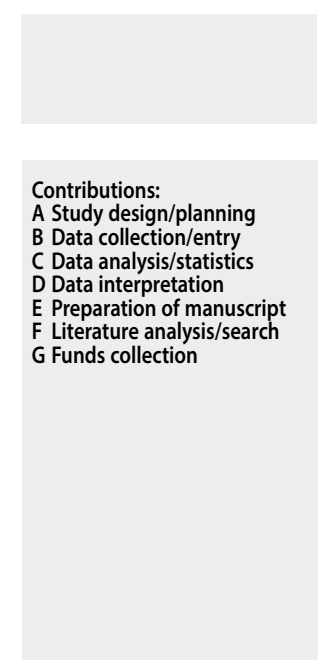

\title{
HEARING LOSS IN SHIPYARD WORKERS AND BATTLE CRUISER EMPLOYEES: A PROSPECTIVE STUDY
}

\author{
Christodoulos Dimakis ${ }^{1,2, A-G}$, Alexandros Delidis ${ }^{1, A-G}$, \\ Panagiotis Theodosiadis ${ }^{3, A-B}$, Konstantinos Soulantikas ${ }^{2, A-G}$, \\ Athanasia Gortsali ${ }^{2, A}$, Thomas Nikolopoulos ${ }^{1, A-G}$
}

${ }^{1}$ ENT, University General Hospital Attikon, Greece
${ }^{2}$ ENT, Naval Hospital of Athens, Greece
${ }^{3}$ Ophthalmology, University General Hospital Attikon, Greece

Corresponding author: Christodoulos Dimakis; ENT, University General Hospital Attikon, rimini 1, 12462, Athens, Greece; email: c.dim2111@gmail.com; Phone: +306979956499

\begin{abstract}
Background: Noise-induced hearing loss (NIHL) is a common occupational disease that both shipyard and battle cruiser workers may encounter, since they are both exposed to hazardous noise levels. However, both white- and blue-collar workers are simultaneously exposed to possible daily risk-factors of incident tinnitus and subsequent hearing loss (HL), such as caffeine and smoking. The aim of the present prospective study is to investigate the prevalence of HL in these working groups of the Greek Navy and the Hellenic Shipyard SA (HSY) in Skaramanga, Greece, and to look at the correlation between OHL and hazardous noise levels as well as other individual factors.

Material and methods: During 2015-17, multiple choice questionnaires including questions referring to socio-demographic information, educational level, and daily habits were administered, and audiograms were performed, to 120 male white- and blue-collar workers, aged 23-30 years old. Statistical analysis was conducted using SPSS v.15.

Results: HL in battle cruiser employees was correlated with occupational noise and individual factors such as caffeine, smoking, and educational level. Additionally, HL in shipyard employees was correlated with occupational noise, alcohol and caffeine intake, smoking, and educational level. A higher level of HL appeared to be correlated with higher levels of occupational noise, lower educational level, and larger consumption of caffeine, alcohol, and smoking. Dietary habits were non-significantly statistically correlated with HL in both types of workers.

Conclusions: HL is a disease strongly related to the Navy and the shipyard industry. Therefore, constant monitoring of workers, implementation of hearing conservation programs, and using preventive measures are the cornerstone of preventing and treating HL. More research of HL in Navy employees should be conducted.
\end{abstract}

Key words: smoking $\bullet$ caffeine $\bullet$ NIHL $\bullet$ white-collar workers $\bullet$ blue-collar workers $\bullet$ OHL

\section{UBYTKI SŁUCHU U PRACOWNIKÓW STOCZNI I KRĄŻOWNIKÓW:}

BADANIE PROSPEKTYWNE

\begin{abstract}
Streszczenie
Wprowadzenie: Ubytek słuchu spowodowany hałasem (NIHL) jest powszechną chorobą zawodową, z którą mogą się spotkać pracownicy stoczni i krążowników, ponieważ są oni narażeni na hałas o poziomie niebezpiecznym dla słuchu. Jednak zarówno pracownicy umysłowi, jak i fizyczni są jednocześnie narażeni na możliwe codzienne czynniki ryzyka takie jak kofeina i palenie, które mogą mieć wpływ na wystapienie szumów usznych i późniejszego ubytku słuchu (HL). Celem niniejszego badania prospektywnego jest analiza występowania niedosłuchu wśród przedstawicieli grup pracowników zatrudnionych w Greckiej Marynarce Wojennej (Greek Navy) i w stoczni Hellenic Shipyard SA (HSY) w Skaramangas w Grecji oraz zbadanie korelacji między zawodowymi ubytkami słuchu (OHL) a poziomami hałasu niebezpiecznymi dla słuchu oraz innymi czynnikami indywidualnymi.
\end{abstract}

Materiał i metody: W latach 2015-2017 przeprowadzono badania z wykorzystaniem kwestionariuszy wielokrotnego wyboru, zawierajacych pytania dotyczące informacji społeczno-demograficznych, poziomu wykształcenia i codziennych nawyków, a także wykonano audiometrię tonalną u 120 pracowników umysłowych i fizycznych w wieku 23-30 lat. Analiza statystyczna została przeprowadzona przy użyciu oprogramowania SPSS v.15.

Wyniki: Niedosłuch wśród pracowników krążowników był związany z hałasem w środowisku pracy i indywidualnymi czynnikami, takimi jak spożycie kofeiny, palenie tytoniu i poziom wykształcenia. Natomiast stopień niedosłuchu wśród pracowników stoczni był związany $\mathrm{z}$ hałasem w środowisku pracy, spożyciem alkoholu i kofeiny, paleniem tytoniu oraz poziomem wykształcenia. Wydaje się zatem, że wyższy stopień niedosłuchu jest związany z wyższym poziomem hałasu w środowisku pracy, niższym poziomem wykształcenia oraz większym spożyciem kofeiny i alkoholu, a także paleniem tytoniu. W obu grupach pracowników zwyczaje żywieniowe nie były w sposób statystycznie istotny skorelowane $\mathrm{z}$ niedosłuchem. 
Wnioski: Niedosłuch jest chorobą często występującą wśród pracowników marynarki wojennej i zatrudnionych w przemyśle stoczniowym. Dlatego stałe monitorowanie pracowników, wdrażanie programów ochrony słuchu i stosowanie środków zapobiegawczych jest podstawą profilaktyki i leczenia niedosłuchu. Należy przeprowadzić dalsze badania w kierunku niedosłuchu wśród pracowników floty.

Słowa kluczowe: palenie • kofeina • NIHL • pracownicy umysłowi • pracownicy fizyczni • OHL

\section{Background}

Hazardous, constant, high-level noise exposure is strongly related to occupational hearing loss (OHL), tinnitus, difficulty of understanding speech in background noise, and inability to localize a sound source (1-3). Although it has been well reported that construction, manufacturing, and heavy industry workers are prone to permanent hearing loss, the prevalence of noise-induced hearing loss (NIHL) in white- and blue-collar employees has scarcely been reported in the literature (4-6).

The prevalence of hearing loss and tinnitus in the military population is greater than in the general public. Almost every soldier, sailor, airman, or marine will be exposed to hazardous noise levels at some point in their career (7-9). The two most prevalent service-connected disabilities for veterans in the United States at the end of fiscal year 2012 remain tinnitus and hearing loss, with tinnitus affecting 115,638 veterans $(9.7 \%)$ and hearing loss affecting 69,326 veterans (5.8\%) (10). Hearing acuity is a key component of a soldier's effectiveness in the battlefield. The presence of tinnitus and hearing loss can significantly impair a soldier's ability to hear important acoustic cues or communication signals from the unit or the enemy (7). Hearing problems can also be a reason for disruption of their military service.

NIHL has a subtle onset and primary vestibular symptoms are typically neglected from workers, since their functional abilities are not restricted (7-8). Indeed, long-term high noise exposure in the occupational environment may lead to insidious symptoms prior to the establishment of potential disability and clinically detectable NIHL $(5,9)$. In this context, audiometric testing is the cornerstone of early and prompt diagnosis of OHL, especially in high-noise exposed employees, such as those in battle cruisers and shipyard workers (5).

Many countries worldwide have rules and regulations in order to protect employees from damaging their hearing. An example is the European Directive (2003/10/EC) that provides both exposure limit values and exposure action values with respect to daily and weekly exposures (11). One of the main goals of hearing conservation programs is to detect hearing loss as soon as possible and halt further deterioration (12). A key role in such a program is measurement of hearing status, traditionally assessed by puretone audiometry. Other methods that are used in hearing testing in occupational settings, either separately or in conjunction with audiometry, are speech-in-noise testing (13) and the measurement of otoacoustic emissions (OAEs) (14-17). However, a systematic review of otoacoustic emissions versus audiometry in monitoring hearing loss after long-term noise exposure in 2018 by Helleman and colleagues revealed that hearing threshold level as measured in the pure-tone audiogram is still the reference standard (18). That can probably be explained because of the higher cost and complexity of using other methods.
Although underreported in the literature, a few papers have mentioned high levels of occupational exposure to noise and a high prevalence of NIHL is documented in Greek industry workers and Greek white- and blue-collar employees $(6,10-11)$. Hence, the aim of the present study is the investigation of the prevalence of HL in these working groups of the Greek Navy and of the correlation between hazardous noise (and other individual factors) with OHL.

\section{Materials and methods}

During 2015-17, a prospective study was conducted in the Greek Navy and the Hellenic Shipyards (HSY) using 40 shipyard and 40 battle cruiser workers (engineers) who were exposed to high occupational noise $(90 \mathrm{~dB})$ and 40 whitecollar workers who were not working in noisy environment for comparison (control group). All the employees were male, aged 23-30 years old. All the participating subjects read and signed a written informed consent in order to participate in the study.

The subjects included in the present study were young workers, aged $<40$ years, who had worked less than one year at the Greek Navy. These inclusion criteria permit the investigation of the relation between occupational noise exposure and NIHL without the interference of the factors "age" and "potential previous ear trauma" that both affect hearing loss. Subjects excluded were workers who had a family or personal history of congenital deafness, otosclerosis, or Meniere's disease, previous ear surgery, or moderate to severe head trauma, constant exposure to ototoxic agents (e.g. salicylates, carbon monoxide, aminoglycoside antibiotics, anti-tuberculosis drugs, lead), or a systematic disease that could affect hearing ability such as poorly controlled diabetes for more than five years or hypertension.

\section{Study population}

The subjects consisted of 120 male white- and blue-collar employees of the Greek Navy and the HSY, in Athens. For this study i) 40 white-collar workers (managers, engineers, inspectors, supervisors, store workers, accountants, material suppliers, clerks, and computer operators) aged 23-30 years (mean $25.6 \pm 5.6$ ) were assigned into the control group and ii) two separate groups of blue-collar workers who were exposed to moderate or high levels of noise were recruited in the study as well. The blue-collar workers were divided into a) 40 shipyard workers (welders, riggers, propeller fitters, dry-dock laborers, chippers, riveters, plate fitters, flame cutters, platters, blasters) aged 25-30 years (mean $28.8 \pm 1.2$ ) and b) 40 battle cruiser workers (practical engineers) aged $23-30$ years (mean $27 \pm 2.5$ ).

\section{Data collection}

The researchers collected data from the subjects for 24 months, with audiometric tests and a questionnaire. The first assessment was performed between November 2015 and January 2016, and the follow-ups (repeat 
audiometric tests) were conducted during the period November 2017 to January 2018.

The questionnaire that was applied to the subjects included 16 questions relating to socio-demographic information, subject's educational level, alcohol, smoking, caffeine, sugar, salt, cocoa, tea, meat, and added flavoring consumption, employment history, auditory-related symptoms such as vertigo or tinnitus, other diseases, and exposure to ototoxic agents such as salicylates, lead, loop diuretics, carbon monoxide, aminoglycoside antibiotics, and chemotherapy drugs. The questionnaire used in the present research is included as an Appendix.

The subjects' noise exposure was measured by experts at the three different occupational environments with a Digital Sound Level Meter 8922 (AZ Instrument Corp) at random working days. Noise exposure was not analyzed outside of working hours in each of these groups; nevertheless each person was advised to avoid exposure to loud noise. People participating in the study did not listen to music through headphones, did not attend concerts, and did not go to clubs. Moreover, despite the diversion of professions in the control group, each of these professions was noisefree. In addition, the subjects' hearing ability was examined via a Pure Tone Audiogram (PTA) with an AC40 clinical hybrid audiometer (Interacoustics). Their hearing ability was measured at the beginning of the study and at a follow-up 2 years later, at 125, 250, 500, 1000, 2000, 4000, 6000 , and $8000 \mathrm{~Hz}$ for both ears.

\section{Statistical analysis}

Descriptive statistics for categorial variables was accumulated by frequency analysis. The analysis of the distribution and percentages for the categorial variables in relation to the noise exposure was performed with contingency tables. The differences in continuous variables such as noise exposure across the three separate groups was assessed by Student's $t$-test. Then, in order to detect predictors of hearing loss, one-way anova tests were performed. The independent variables were demographic information, factors relevant to hearing loss and individual confounding factors (e.g. alcohol consumption habits) and the dependent variable was the audiometric test. As a measure of association, odds ratios (ORs) with $95 \%$ confidence intervals (CIs) were measured. The statistical analysis was conducted with the Statistical Package for the Social Sciences (SPSS) v.15 software (IBM, Armonk, NY).

\section{Ethics}

Written approval for the present study was given by the Greek Navy and the ethical committee of the hospital where the audiometric tests were performed. In addition, all the included subjects read and signed a written informed consent and participated in the study voluntarily.

\section{Results}

The first audiometric test, performed at the beginning of the study, revealed that all subjects in the three separate groups had low thresholds at the examined frequencies and had no previous hearing disorders (Figures 1, 2, 3).
The results of the repeat audiometric tests were analyzed with paired samples $t$-tests in order to document statistically significant hearing ability alterations correlated to high noise exposure. In the unexposed group of whitecollar workers no statistically significant alterations were detected (Figure 4).

In the battle cruiser workers group though, statistically significant hearing disability was revealed at high frequencies. In fact, at $4000 \mathrm{~Hz}$ the audiometric test of the right ear was higher (average price (A.P.) $=20.88$, standard deviation (S.D.) $=11.92$ ) than the first one

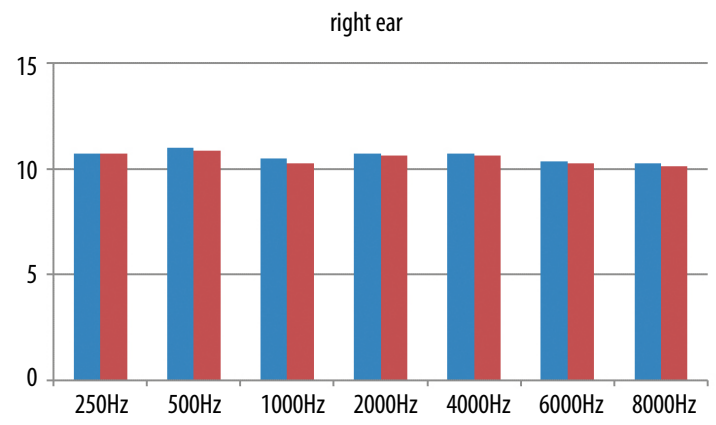

Figure 1. Right ear, control group. Comparison for right ear between first (blue bar) and second (red bar) audiogram in the control group. Axes show average levels of hearing thresholds across frequencies

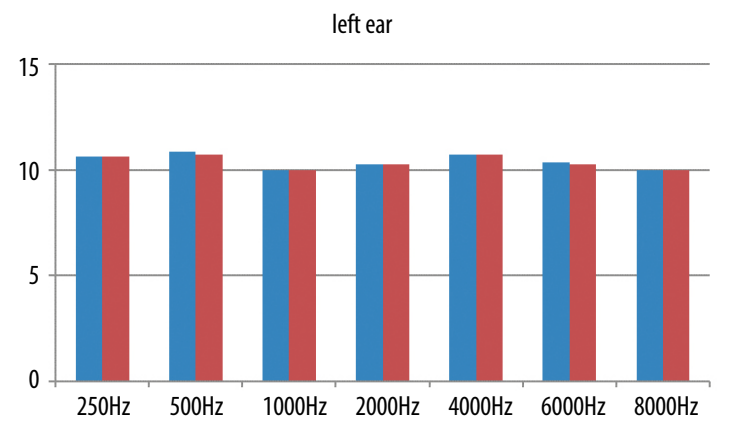

Figure 2. Left ear, control group. Comparison for left ear between first (blue) and second (red) audiogram in the control group. Axes as per Figure 1

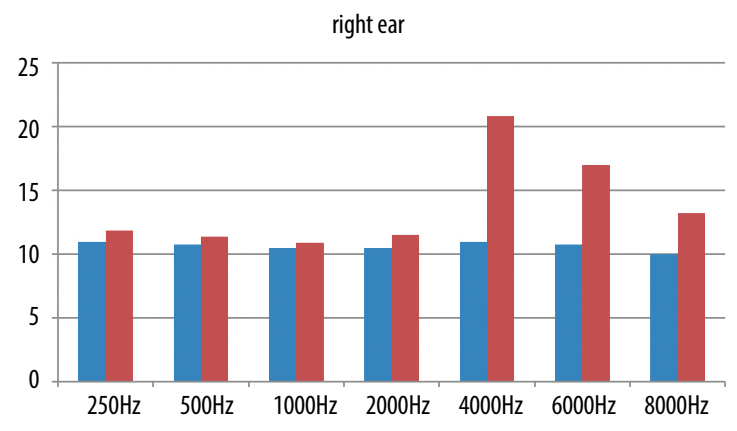

Figure 3. Right ear, battlecruiser workers. Comparison for right ear between first (blue) and second (red) audiogram in battlecruiser workers group 
(A.P. $=11$, S.T. $=2.03)$ and the hearing loss was statistically significant $(t(39)=-5.27, p=.000<.05)$. Similarly, at $6000 \mathrm{~Hz}$ the difference was $(t(39)=-3.55, p=.001<.05)$ and at $8000 \mathrm{~Hz}(t(39)=-2.48, p=.018<.05)$. Similar findings were detected for the left ear of this group as well as at $4000 \mathrm{~Hz}(t(39)=-6.55, p=.000<.05)$, at $6000 \mathrm{~Hz}(t(39)=-4.32, p=.000<.05)$, and at $8000 \mathrm{~Hz}$ $(\mathrm{t}(39)=-3.66, p=.001<.05)$ (Figure 5).

In the shipyard workers group, statistically significant hearing disability was revealed mostly at high frequencies $(4000,6000,8000 \mathrm{~Hz})$. The repeat audiometric test of the right ear revealed statistically significant changes of hearing

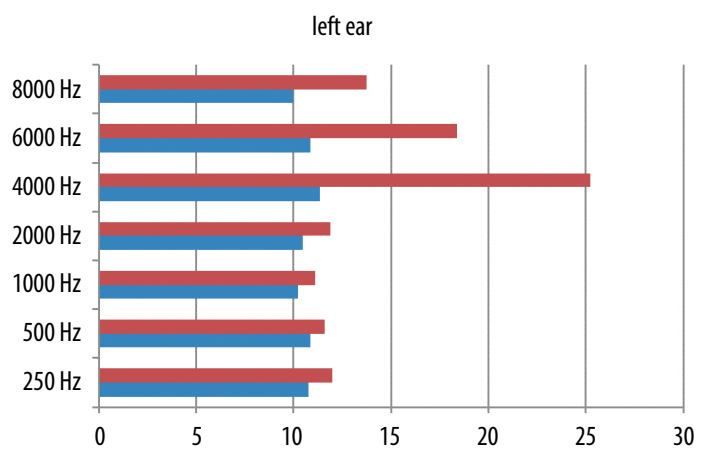

Figure 4. Left ear, battlecruiser workers. Comparison for left ear between first (blue) and second (red) audiogram in battlecruiser workers group

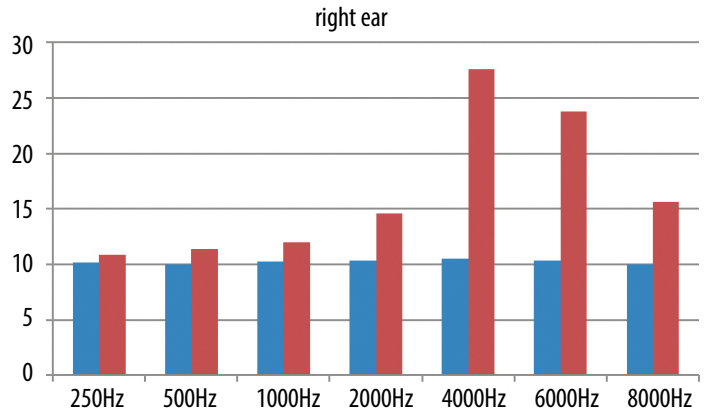

Figure 5. Right ear, shipyard workers. Comparison for right ear between first (blue) and second (red) audiogram in shipyard workers group

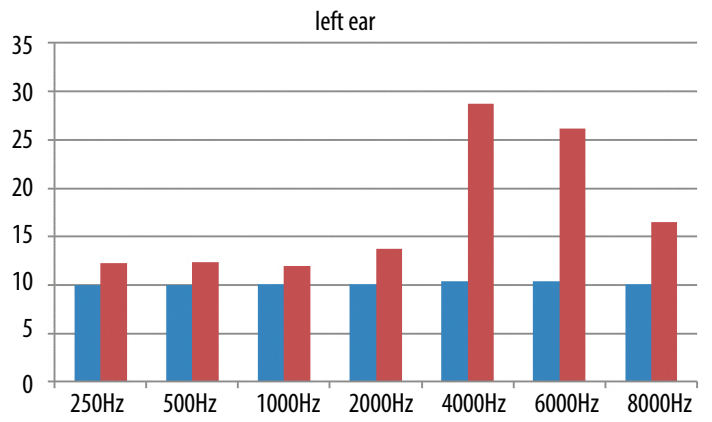

Figure 6. Left ear, shipyard workers. Comparison for left ear between first (blue) and second (red) audiogram in shipyard workers group ability at $2000 \mathrm{~Hz}(t(39)=-2.57, p=.014<.05), 4000 \mathrm{~Hz}$ $(t(39)=-5.12, p=.000<.05), 6000 \mathrm{~Hz}(t(39)=-5.4, p=.000<.05)$, and $8000 \mathrm{~Hz}(t(39)=-3.14, p=.003<.05)$. The hearing ability at $2000 \mathrm{~Hz}$ at the first test had A.P. 10.38 instead of the one of the repeat audiometric test (A.P. 14.63) which means that the hearing ability had decreased about $4.25 \mathrm{~dB}$. Similarly, workers' hearing ability at $4000 \mathrm{~Hz}$ was decreased about $17.13 \mathrm{~dB}$ after two years at the shipyard. Similar findings were detected for the left ear at $4000 \mathrm{~Hz}(\mathrm{t}(39)=-5.33, p=.000<.05)$, $6000 \mathrm{~Hz}(t(39)=-4.98, p=.000<.05)$, and $8000 \mathrm{~Hz}$ $(\mathrm{t}(39)=-2.77, p=.008<.05)$ indicating hearing loss $($ Figure 6).

One-way Anova tests were performed to detect the effect on hearing loss of variables such as educational level, alcohol, smoking, caffeine, sugar, salt, cocoa, tea, meat, and added flavoring consumption. The measuring scale for smoking in the questionnaires was 1: never, 2 or rarely: up to 1 cigarette per day, 3 or sometimes: from 2 to 5 cigarettes per day, 4 or frequently: from 6 to 15 cigarettes per day, 5 or much: more than 16 cigarettes per day. The measuring scale for coffee and alcohol consumption in the questionnaires was 1: never, 2 or rarely: 1 cup $(250 \mathrm{~mL})$ per week, 3 or sometimes: from 2 to 4 cups per week, 4 or frequently: from 5 to 7 cups per week, 5 or much: more than 1 cup daily.

At the unexposed group no statistically significant alterations were detected correlated to nutritional habits or smoking and alcohol consumption.

However, in the battle cruiser workers group, statistically significant hearing loss of the right ear correlated with smoking habits was detected at $4000 \mathrm{~Hz}(F(4,35)=5.62, p=.001<.05)$ and at $6000 \mathrm{~Hz}(F(4,35)=9.01, p=.000<.05)$ and of the left ear at $4000 \mathrm{~Hz}(F(4,35)=4.02, p=.009<.05)$ and $6000 \mathrm{~Hz}(F(4,35)=3.47, p=.017<.05)$ (Figure 7). Posthoc analysis of the same group showed statistically significant changes of hearing ability at $4000 \mathrm{~Hz}$ and $6000 \mathrm{~Hz}$ in the right ear and at $4000 \mathrm{~Hz}, 6000 \mathrm{~Hz}$, and $8000 \mathrm{~Hz}$ in the left ear between workers who consumed caffeine never, rarely, sometimes, and often and those who consumed very much caffeine (Figure 9).

In the group of shipyard workers, there were no statistically significant differences correlated to nutritional habits but statistically significant change of hearing acuity of the right ear at $2000 \mathrm{~Hz}$ $(F(4,35)=7.17, p=.000<.05), 4000 \mathrm{~Hz}(F(4,35)=23.65$, $p=.000<.05,6000 \mathrm{~Hz}(F(4,35)=22.89, p=.000<.05)$, and $8000 \mathrm{~Hz}(F(4,35)=5.83, p=.001<.05)$ was detected in smokers. Post hoc analysis, revealed differences at $2000,4000,6000$, and $8000 \mathrm{~Hz}$ between those who never or sometimes smoked and those who smoked very much. Similar findings were documented concerning the left ears of the subjects at $2000 \mathrm{~Hz}$ $(F(4,35)=3.52, p=.016<.05), 4000 \mathrm{~Hz}(\mathrm{~F}(4,35)=30.95$, $p=.000<.05,6000 \mathrm{~Hz}(F(4,35)=18.39, p=.000<.05)$, and $8000 \mathrm{~Hz}(F(4,35)=6.45, p=.001<.05)($ Figure 8).

In addition, regression analysis indicated that alcohol consumption affected hearing acuity of this group. In fact the audiometric test of the right ear at $250 \mathrm{~Hz}$ $(F(3,36)=4.27, p=.011<.05), 500 \mathrm{~Hz}(F(3,36)=3.08$, 
$p=.04<.05)$, and $1000 \mathrm{~Hz}(F(3,36)=4.39, p=.01<.05)$ showed loss of hearing ability correlated to alcohol. Subsequent post-hoc analysis revealed statistically significant differences at 250,500 , and $1000 \mathrm{~Hz}$ between shipyard workers that did not drink alcohol, drank rarely, or drank sometimes and those who drank alcohol often. Regression analysis indicated the impact of caffeine consumption on hearing loss as well. Statistically significant hearing loss of the right ear was found at $4000 \mathrm{~Hz}(F(4,35)=7.86, p=.000<.05)$ and $6000 \mathrm{~Hz}(F(4,35)=6.12, p=.001<.05)$ and of the left ear at $4000 \mathrm{~Hz}(F(4,35)=9.78, p=.000<.05)$ and $6000 \mathrm{~Hz}(F(4,35)=7.94, p=.000<.05)$. Post hoc analysis delineated statistically significant hearing loss of both ears at 4000 and $6000 \mathrm{~Hz}$ in the workers who consumed a lot of coffee compared to those who did not drink, or rarely drank, coffee (Figure 10).

Finally, the impact of educational level on hearing loss was examined in all the subject groups using regression analysis. The majority of white-collar workers, whose hearing ability remained intact, were graduates of higher education institutions $(82.5 \%)$ and $17.5 \%$ had completed secondary education.

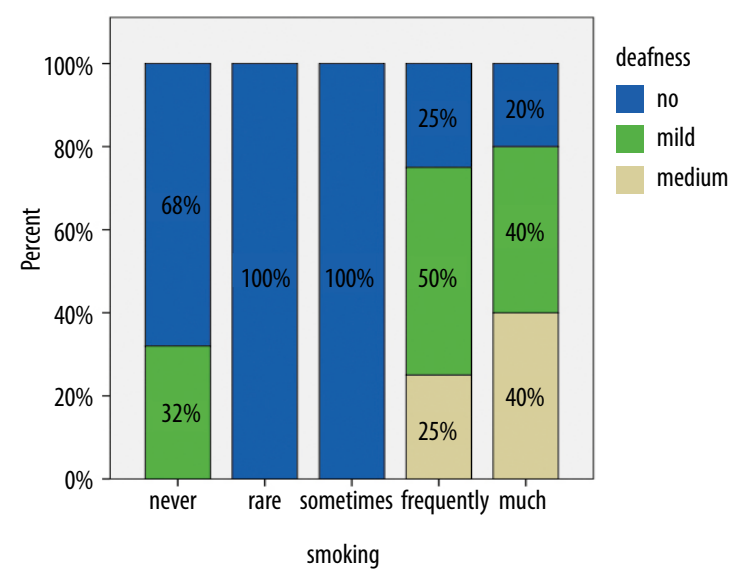

Figure 7. Comparison of smoking habit and hearing loss in battle cruiser workers. No: no hearing loss; mild: hearing thresholds 21-40 dB; medium: hearing thresholds 41-60 dB; high: hearing thresholds higher than $61 \mathrm{~dB}$

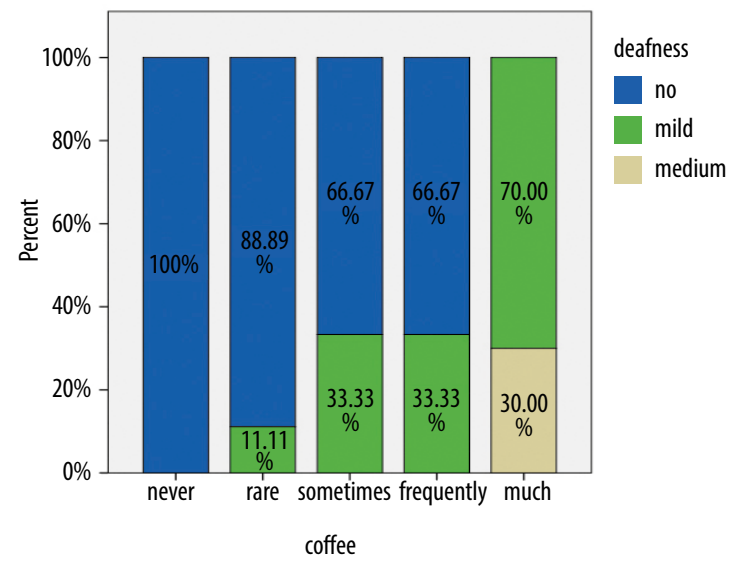

Figure 9. Comparison of coffee consumption and hearing loss in battle cruiser workers. Key as per Figure 7
The battle cruiser workers were alums of higher education (65\%) and secondary education (35\%). The impact of low educational level in hearing decrease was statistically significant for the right ear at $4000 \mathrm{~Hz}(F(2,37)=9.07, p=.001<.05)$ and $6000 \mathrm{~Hz}(F(2,37)=8.83, p=.001<.05)$ and the left ear at $4000 \mathrm{~Hz}(F(2,37)=7.09, p=.002<.05$ and $6000 \mathrm{~Hz}$ $(F(2,37)=9.97, p=.000<.05)$. Tukey's HSD post hoc test detected statistically significant differences between hearing loss and educational level in both left and right ears (Figure 11).

The shipyard workers were alums of higher education (65\%), alums of secondary education $(27.5 \%)$, and of primary education (7.5\%). The effect of this variable on hearing loss was measured as statistically significant at $2000 \mathrm{~Hz}$ $(F(3,36)=4.76, p=.007<.05), 4000 \mathrm{~Hz}(F(3,36)=9, p=.000<.05$, $6000 \mathrm{~Hz}(F(3,36)=12.37, p=.000<.05)$, and $8000 \mathrm{~Hz}$ $(F(3,36)=3.47, p=.026<.05)$ for the right ear and $4000 \mathrm{~Hz}(F(2,37)=7.09, p=.002<.05)$ and $6000 \mathrm{~Hz}$ $(F(2,37)=9.97, p=.000<.05)$ for the left. Tukey's HSD post hoc analysis indicated statistically significant difference at 2000, 4000,6000, and $8000 \mathrm{~Hz}$ between the three separate educational level groups for both ears (Figure 12).

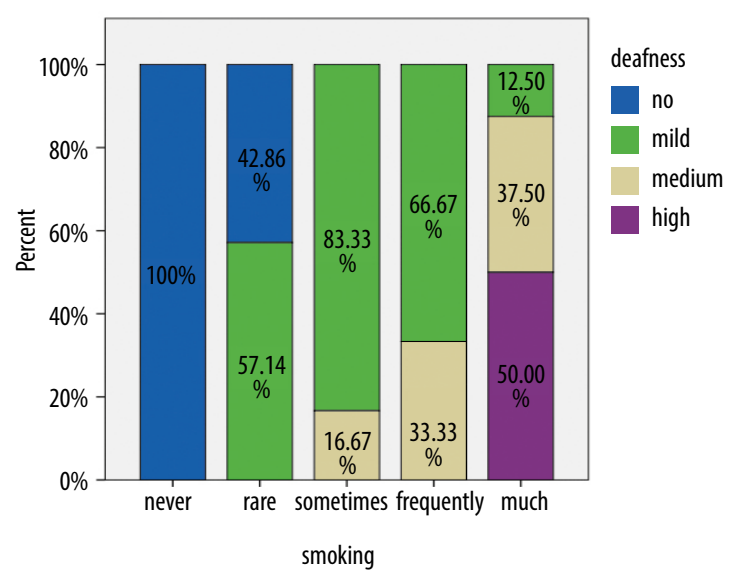

Figure 8. Comparison of smoking habit and hearing loss in shipyard workers. Key as per Figure 7

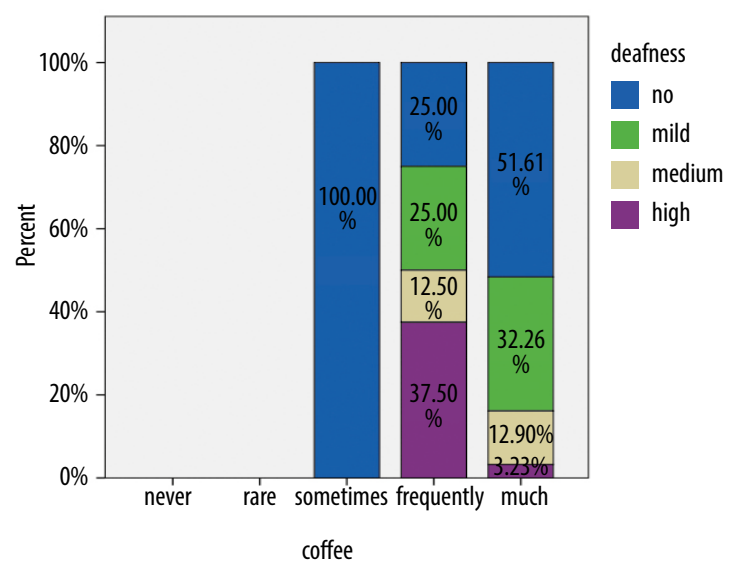

Figure 10. Comparison of coffee consumption and hearing loss in shipyard workers. Key as per Figure 7 


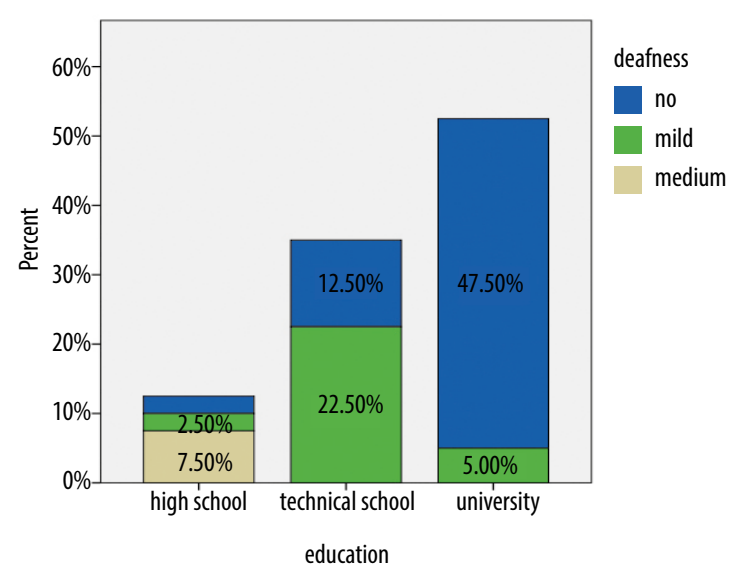

Figure 11. Comparison of educational level and hearing loss in battle cruiser workers. Key as per Figure 7

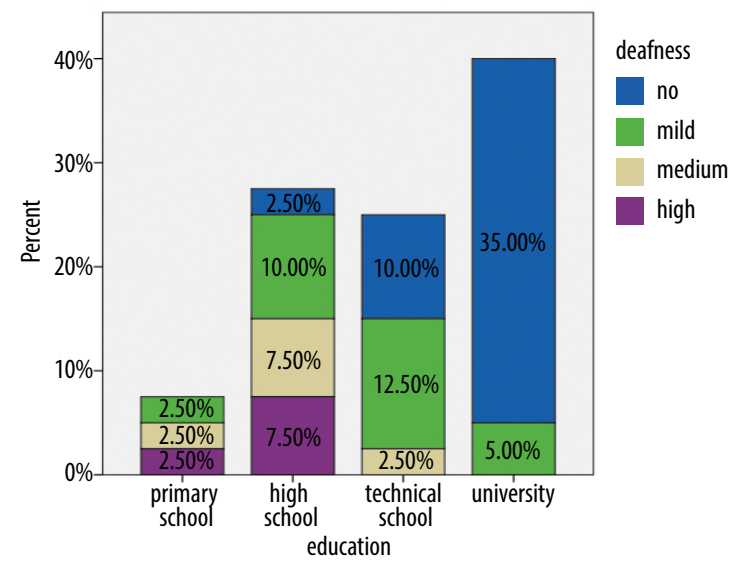

Figure 12. Comparison of educational level and hearing loss in shipyard workers. Key as per Figure 7

\section{Discussion}

In the present study a high percentage of blue-collar workers were found to be prone to NIHL. The variables of educational level, caffeine and alcohol consumption, and smoking habits also had an important impact on HL. It was detected that apart from the variables of age and medical condition, that are well documented in the literature to affect hearing acuity $(6,24-26)$, occupational exposure to high noise was related with statistically significant hearing loss in both shipyard and battle cruiser employees after 2 years of work.

Although the obligation to control occupational high-noise exposure is a legislated area in Greece (6), the present paper indicates the necessity of reexamining these regulated areas, since blue-collars are assailable to OHL and a large percentage presented hearing decrease after 2 years of exposure to their occupational environment. Indeed, it was discovered that the blue-collars of the Greek Navy were exposed on a daily basis to $>60 \mathrm{~dB}$ and sometimes $>90 \mathrm{~dB}$. Additionally, although NIHL constitutes a common occupational disease of construction, manufacturing, and heavy industry workers, its prevalence in blue-collar employees is rarely reported in the literature and especially in Greece (4-6, 27-28).
Inagreement with other studies, this study recognizes high noise exposure as one of the most important factors for the inducement of hearing impairment $(1,5-6)$. As expected, hearing loss in white-collars is not statistically significant since they are not exposed to high-noise (6,29-30). On the other hand, battle cruiser workers presented statistically significant hearing loss, and shipyard employees even bigger, as expected (6).

In the present study, nutritional habits were found as not statistically significant variables correlated with HL in either white- or blue-collar workers. However, alcohol consumption was estimated as a variable with paramount importance in shipyard workers. That could be explained if we take into consideration that there was a higher consumption of alcohol among shipyard workers compared to other professional groups according to the answers in the questionnaires. In the literature several studies suggest that alcohol may influence hearing acuity (31) probably because of disturbance in cochlear blood flow (32). Indeed, constant alcohol abuse has been associated with hearing impairment (33), but according to cross-sectional studies moderate consumption of alcohol may have a protective effect on hearing ability (34-35).

In addition, in the present study caffeine consumption and smoking habits were found to affect hearing ability of both groups of blue-collar workers. The relation between caffeine intake and HL is not yet understood, but it is possible that caffeine consumption is common in people involved in noise-related occupational environments (36). However, we are in need of more research so that we can conclusively point to this phenomenon. On the other hand, smoking is correlated with a potential risk of HL in a dose-response manner (37). The excess risk of HL is associated with the short period after quitting smoking (37).

Finally, as expected, an additional and important effect of OHL is the educational level of the workers (6). Thus, it is more likely for lower educated workers to be involved in higher noise occupational environments and thereby be more assailable to developing NIHL, as documented in other studies $(6,38)$. However, these results could be explained by considering that higher educated workers might have used protective measures such as earplugs more frequently. Furthermore, it is possible that higher educated workers consumed less caffeine and smoked less. Their educational level might allow them to have knowledge of the hearing risks regarding noise. Although this justification may seem reasonable, a statistical analysis between educational level and the usage of protection measures or daily habits has not been done in the present study.

The present study used accurate methods for the estimation of hearing ability. Data was collected via audiometric tests by experts of the relevant health department of a Greek Hospital, and are considered of very high validity. However, the limitations of the study were: a) assessment of HL after only 2 years of work, and b) the fact that personal exposure measurements were not done due to the complex occupational environment of blue-collar workers in the Greek Navy.

Finally, the present study strengthens existing evidence that NIHL due to occupational high-noise exposure is a potential 
and uncontrolled issue in Greece and other countries as well $(6,39)$. Besides, since 1991, only a few studies have been published and the public is not aware of the prevalence and the importance of NIHL (6).

\section{Conclusion}

NIHL is a severe and common health disorder, and only a few studies concerning the surveillance and prevention of this disorder have been published. Especially in Greece, there are very few published studies concerning high-noise occupational exposure and HL. However, as the present study and similar ones in the literature, there is an evident correlation between occupational exposure and hearing disorders. Therefore, there is an evident need for a) further studies including audiometric tests of blue-collar workers and workers in the area of construction and industry, b) comprehensive hearing conservation programs, c) reexamining the legislated areas referring to control of occupational high-noise exposure, and d) education of the public in order to increase awareness about NIHL and its prevention. Our findings refer to a statistically important relation between smoking, alcohol and coffee consumption, and hearing loss, so further studies should focus on these domains apart from occupational high-noise exposure. Early diagnosis of NIHL and prompt treatment, but most importantly the prevention of NIHL, are the cornerstones of its abatement.

\section{Appendix}

\section{Questionnaire}

\section{Male $\square$ Female $\square$}

Age:

Educational level:

- Graduate of primary education $\square$

- Graduate of secondary education $\square$

- Graduate of technological institution $\square$

- Graduate of university $\square$

Do you have any disease of the ear? If yes, (mention: ...) No

Did you take any medicine the last two months? If yes, (mention: ...................) No

Do you have any systematic disease? If yes, (mention: ..................) No

Have you ever experienced a hearing disorder? If yes, (mention the ear that experienced the problem: ..) No

Have you been exposed to environmental noises? Yes/ No If yes:

- How long?

- Which was the sounds' level?

\section{References}

1. Pelegrin AC, Canuet L, Rodríguez ÁA, Morales MP. Predictive factors of occupational noise-induced hearing loss in Spanish workers: a prospective study. Noise Health, 2015 Sep-Oct; 17(78): 343-9.

2. Masterson EA, Tak S, Themann CL, Wall DK, Groenewold MR, Deddens JA, Calvert GM. Prevalence of hearing loss in the United States by industry. Am J Ind Med, 2013 Jun; 56(6): 670-81.

3. Suter AH. Construction noise: exposure, effects, and the potential for remediation; a review and analysis. AIHA J, 2002 NovDec; 63(6): 768-89.

4. Hong O, Lusk SL, Ronis DL. Ethnic differences in predictors of hearing protection behavior between black and white workers. Res Theory Nurs Pract, 2005;19: 63-76.

5. Palmer, KT, Coggon, D, Syddall, HE, Pannett, B, Griffin, MJ. Occupational exposure to noise and hearing difficulties in Great Britain. Suffolk: HSE Books, 2001

6. Alexopoulos EC, Tsouvaltzidou T. Hearing loss in shipyard employees. Indian J Occup Environ Med, 2015 Jan-Apr; 19(1): 14-18.

7. Yankaskas K. Prelude: noise-induced tinnitus and hearing loss in the military. Hear Res, 2013; 295: 3-8.
Do you have some of the following habits?

(score with the following numbers. 1: never, 2: rarely,

3: sometimes, 4: often, 5: daily or very much)

- Smoking Yes (how much...............) No

- Alcohol consumption: Yes (how much...............) No

- Drugs consumption: Yes (how much...............) No

- Salt consumption: Yes (how much..............) No

- Sugar consumption: Yes (how much...............) No

- Food adds consumption: Yes (how much...............) No

- Meat and fried food consumption: Yes (how much..........) No

- Coffee consumption: Yes (how much...............) No

- Tea consumption: Yes (how much...............) No

- Cocoa Consumption: Yes (how much...............) No

For smoking 1: never, 2: until 1 cigarette per day , 3: from 2 to 5 cigarettes per day, 4 : from 6 to 15 cigarettes per day, 5: more than 16 cigarettes per day.

For coffee tea and alcohol 1: never, 2: 1 cup $(250 \mathrm{ml})$ per week, 3: from 2 to 4 cups per week, 4 : from 5 to 7 cups per week, 5: more than 1 cup daily.

8. Pfannenstiel TJ. Noise-induced hearing loss: a military perspective. Curr Opin Otolaryngol Head Neck Surg, 2014; 22: 384-7.

9. Collee A, Legrand C, Govaerts B, Van Der Veken P, De Boodt F, Degrave E. Occupational exposure to noise and the prevalence of hearing loss in a Belgian military population: a cross-sectional study. Noise Health, 2011; 13: 64-70.

10. Annual Benefits Report, Fiscal Year 2012. Department of Veteran Affairs, 2012.

11. Directive 2003/10/EC of the European Parliament and of the Council of 6 February 2003 on the minimum health and safety requirements regarding the exposure of workers to the risks arising from physical agents (noise) (Seventeenth individual Directive within the meaning of Article 16(1) of Directive 89/391/ EEC). Official Journal of the European Union 46(42): 38-44.

12. Kirchner DB, Evenson E, Dobie RA, Rabinowitz P, Crawford J, Kopke R, et al. ACOEM Task Force on Occupational Hearing Loss. J Occup Environ Med, 201254(1): 106-8.

13. Leensen MC, Dreschler WA. The applicability of a speech-innoise screening test in occupational hearing conservation. Int J Audiol, 2013; 52(7): 455-65. 
14. Feder K, Michaud D, McNamee J, Fitzpatrick E, Davies H, Leroux T. Prevalence of hazardous occupational noise exposure, hearing loss, and hearing protection usage among a representative sample of working Canadians. J Occup Environ Med, 2017; 59(1), 92-113.

15. Forshaw C. Report of an International Expert Symposium on the Usefulness of Otoacoustic Emissions (OAE) Testing in Occupational Health Surveillance, 8-9 February 2011. Manchester: Corporate Medical Unit, Health \& Safety Executive, 2011.

16. Marshall L, Lapsley Miller JA, Heller LM. Distortion-product otoacoustic emissions as a screening tool for noise-induced hearing loss. Noise Health, 2001; 3(12): 43-60.

17. Sliwinska-Kowalska M, Kotylo, P. Otoacoustic emissions in industrial hearing loss assessment. Noise Health, 2001; 3(12): 75-84.

18. Helleman HW, Eising H, Limpens J. Otoacoustic emissions versus audiometry in monitoring hearing loss after long-term noise exposure: a systematic review. Scand J Work Environ Health, 2018 Nov 1; 44(6): 585-600.

19. Ologe FE, Olajide TG, Nwawolo CC, Oyejola BA. Deterioration of noise-induced hearing loss among bottling factory workers. J Laryngol Otol, 2008 Aug; 122(8): 786-94.

20. Masterson EA, Themann CL, Calvert GM. Prevalence of hearing loss among noise-exposed workers within the agriculture, forestry, fishing, and hunting sector, 2003-2012. Am J Ind Med, 2018 January; 61(1): 42-50.

21. U.S. Department of Commerce, The Kraus Organization Limited. North American Industry Classification System: United States. White Plains, MD: Automated Graphic Systems, Inc; 2007.

22. Social Insurance Institute - Unified Insurance Fund of Employees: Occupational Diseases 2009 and Retrospective Data for 2003-2009.

23. Rachiotis G, Alexopoulos C, Drivas S. Occupational exposure to noise, and hearing function among electro production workers. Auris Nasus Larynx, 2006; 33: 381-5.

24. Ruan Q, Ma C, Zhang R, Yu Z. Current status of auditory aging and anti-aging research. Geriatr Gerontol Int, 2014; 14: 40-53.

25 . Kidd AR, Bao J. Recent advances in the study of age-related hearing loss: a mini-review. Gerontology, 2012; 58: 490-6.

26. Chole RA, McKenna M. Pathophysiology of otosclerosis. Otol Neurotol, 2001; 22: 249-57.

27. Alexopoulos EC, Kavadi Z, Bakoyannis G, Papantonopoulos S. Subjective risk assessment and perception in the Greek and English bakery industries. J Environ Public Health, 2009; 2009: 891754.
28. Nilsson R, Lidén G, Sandén A. Noise exposure and hearing impairment in the shipbuilding industry. Scand Audiol, 1977; 6: 59-68.

29. Prince MM. Distribution of risk factors for hearing loss: implications for evaluating risk of occupational noise-induced hearing loss. J Acoust Soc Am, 2002; 112: 557-67.

30. Curhan SG, Eavey R, Shargorodsky J, Curhan GC. Prospective study of alcohol use and hearing loss in men. Ear Hear, 2011 Feb; 32(1): 46-52.

31. Seidman MD, Quirk WS, Shirwany NA. Mechanisms of alterations in the microcirculation of the cochlea. Ann N Y Acad Sci, 1999; 884: 226-32.

32. Rosenhall U, Sixt E, Sundh V, Svanborg A. Correlations between presbyacusis and extrinsic noxious factors. Audiology, 1993; 32: 234-43.

33. Fransen E, Topsakal V, Hendrickx JJ et al. Occupational noise, smoking, and a high body mass index are risk factors for age-related hearing impairment and moderate alcohol consumption is protective: a European population-based multicenter study. J Assoc Res Otolaryngol, 2008; 9: 261-3.

34. Helzner EP, Cauley JA, Pratt SR et al. Race and sex differences in age-related hearing loss: the Health, Aging and Body Composition Study. J Am Geriatr Soc, 2005; 53: 2119-27.

35. Zawawi F, Bezdjian A, Mujica-Mota M, Rappaport J, Daniel SJ. Association of caffeine and hearing recovery after acoustic overstimulation events in a guinea pig model. JAMA Otolaryngol Head Neck Surg, 2016 Apr; 142(4): 383-8.

36. Hu H, Sasaki N, Ogasawara T et al. Smoking, smoking cessation, and the risk of hearing loss: Japan Epidemiology Collaboration on Occupational Health Study. Nicotine \& Tobacco Research. April 2019; 21(4): 481-8.

37. Mahboubi H, Zardouz S, Oliaei S, Pan D, Bazargan M, Djalilian HR. Noise-induced hearing threshold shift among US adults and implications for noise-induced hearing loss: National Health and Nutrition Examination Surveys. Eur Arch Otorhinolaryngol, 2013; 270: 461-7.

38. Greek Ministry of Labour and Social Insurance. Presidential Decree 85/91: Protection of Workers from the Risks Related to Exposure to Noise at Work, in Compliance with Directive 86/188/ EEC. 1991.

39. Fernández MD, Quintana S, Chavarría N, Ballesteros JA. Noise exposure of workers of the construction sector. Appl Acoust, 2009; 70: 753-60. 